\title{
アルミニウム合金サンドイッチパネルの捩り TORSION OF ALUMINIUM ALLOY SANDWICH PANELS
}

\author{
井上哲 郎*, 木村 衛** \\ Tetsurou INOUE and Mamoru KIMURA
}

This study is an experimental confirmation of torsional behavior of alminium alloy sandwich panels.

Five series of panels were tested. And these are grouped into three classes such as adhesive brazed and urethane panels.

Adhesive panels consists of two series with different sizes of honeycomb core.

Brazed panel consists of two series with different types of cores such as honeycomb and round core. Explanations of initial stiffness, ultimate strength and inelastic behavior are tried by the method of simple multi-cell substitution.

Keywords: Torsion, Aluminium alloy, Sandwich panel, Honeycomb core, Circular core, Urethane core 㨝り，アルミニウム合金，サンドイッチパネル，ハニカムコア， 丸コア, ウレタンコア

1.はじめに

サンドイッチパネルを構造壁として利用する場合、縌長形状にな ると横荷重に対して面外に不安定となり、横座屈の検討が必要とな る。この観点からサンドイッチパネルの㨭り剛性を評価するため、 据り実験を実施した。実験結果を説明するため、サンドイッチパネ ルのコアを隔壁に置換し、マルチセルパネルと仮定して据り剛性評 価を試み、さらに耐力・変形挙動に言及した。

\section{2. 㨭り実験}

\section{1 試験体}

試験体にはハニカムコア $(\mathrm{H}) 、 丸 コ ア （ \mathrm{R})$ およびウレタン $(\mathrm{U}$ R）の三種類のコア材を用いた (図 1 参照)。

試験体には 5 種類のシリーズがある。表 1 を参照して、表面板が等 しく（板厚 $1 \mathrm{~mm}$ 材質 AS130）、コア寸法の異なる接着ハニカムパ ネル H I - $1 \mathrm{~A}$ と H I - 2 A シリーズ、同じく表面板が等しく（板 厚 $2.5 \mathrm{~mm}$ 材質 AS65)、コア形状の異なるロウ付けハニカムパネル H II - 1 B とロウ付け丸コアパネル R II - 1 B シリーズ及びウレタ ンのコア材を持つUR シリーズである。UR シリーズは H I シリー ズと表面板が等しく、ハニカムコアとウレタンコアの比較を可能と する。各シリーズには三種類の異なる幅がある。それぞれのシリー ズの試験体の寸法は表 2 に示されている。試験体素材の機械的性質 は表 3 のとおりである。ただしコア材の素材試験は実施されておら
ず HII， RIIシリーズについては同種の別試験体(6)を参考値として () で示している。

表 1 試験体断面特性

\begin{tabular}{|c|c|c|c|c|c|}
\hline & $\begin{array}{c}\text { 表面板 } \\
\text { 板厚 } \\
t(\mathrm{~mm})\end{array}$ & $\begin{array}{l}\text { コア } \\
\text { 形状 }\end{array}$ & $\begin{array}{c}コ ア \\
\text { 寸法 } \\
d \\
(\mathrm{~mm})\end{array}$ & $\begin{array}{c}\exists ア \\
\text { 箔厚 } \\
t_{c} \\
(\mathrm{~mm})\end{array}$ & $\begin{array}{c}\text { 表面板 } \\
\text { 材質 }\end{array}$ \\
\hline $\mathrm{HI} \cdot \mathbf{1 A}$ & 1.0 & 接着八ニカム & 12.7 & 0.076 & $\mathrm{AS} 130^{\text {注 }}$ \\
\hline $\mathrm{HI} \cdot 2 \mathrm{~A}$ & 1.0 & 接着ハニカム & 9.5 & 0.076 & AS130 \\
\hline $\mathrm{H} \mathrm{II} \cdot 1 \mathrm{~B}$ & 2.48 & ロウ付けハニカム & 20 & 0.2 & AS65 \\
\hline $\mathrm{R} \Pi \cdot 1 \mathrm{~B}$ & 2.48 & ロウ付け丸コア & 20 & 0.2 & AS65 \\
\hline UR & 1.0 & ウレタン & - & - & AS130 \\
\hline
\end{tabular}

注）文献(5)の呼称による。 $\mathrm{AS}$ 一基準強度 $\mathrm{F}$ 值（ $\mathrm{N} / \mathrm{mm}^{2}$ )

*1 折板を接着してハニカム形状のコアとし、 これと表面板を接着したもの。

*2コア部、表面板ともにロウ付けしたもの。

*3 表面板間にポリウレタンフォームを注入、 加圧・加熱したもの
* 筑波大学システム情報工学研究科 教授・工博

** 工イ構造研 代表.工博
Prof., Systems and Information Engineering, The Univ. of Tsukuba, Dr. Eng. Delegate, A Structural Lab., Dr. Eng. 

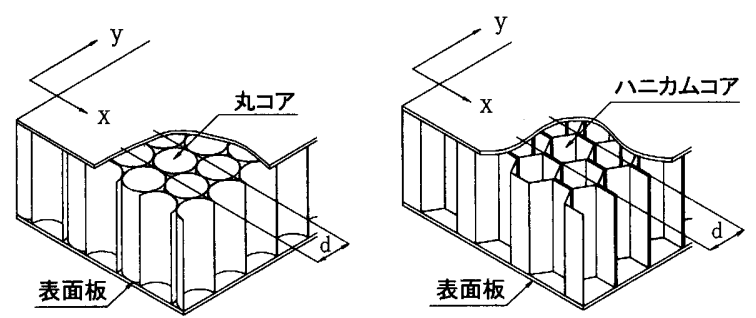

図 1 サンドイッチパネルのコア

表 2 試験体寸法

\begin{tabular}{c||c|c|c}
\hline Code & $\begin{array}{c}\text { パネル幅 } \mathrm{B} \\
(\mathrm{mm})\end{array}$ & $\begin{array}{c}\text { パネル厚 } \mathrm{h} \\
(\mathrm{mm})\end{array}$ & $\begin{array}{c}\text { 有効長 } \mathrm{L} \\
(\mathrm{mm})\end{array}$ \\
\hline-31 & & & 200 \\
-32 & 300 & 50 & 350 \\
-33 & & & 800 \\
\hline-51 & & & 300 \\
-52 & 500 & 50 & 550 \\
-53 & & & 1.300 \\
\hline-81 & & & 450 \\
-82 & 800 & 50 & 850 \\
-83 & & & 1.300 \\
\hline
\end{tabular}

表 3 使用材料の機械的性質

\begin{tabular}{|c|c|c|c|c|c|}
\hline & \multicolumn{2}{|c|}{ 表面板 } & \multicolumn{2}{|c|}{ コア材 } & 備考 \\
\hline Code & $\begin{array}{l}\text { 板厚 } \\
(\mathrm{mm})\end{array}$ & $\begin{array}{c}\sigma 0.2 \% \\
\left(\mathrm{~N} / \mathrm{mm}^{2}\right)\end{array}$ & $\begin{array}{l}\text { 箔厚 } \\
(\mathrm{mm})\end{array}$ & $\begin{array}{c}\sigma 0.2 \% \\
\left(\mathrm{~N} / \mathrm{mm}^{2}\right)\end{array}$ & \\
\hline $\mathrm{HI} \cdot 1 \mathrm{~A}$ & 1.0 & 116 & 0.076 & - & \multirow{4}{*}{ 素材試験による } \\
\hline $\mathrm{HI} \cdot 2 \mathrm{~A}$ & 1.0 & 116 & 0.076 & -- & \\
\hline H II - $1 \mathrm{~B}$ & 2.48 & 87 & 0.2 & (77) & \\
\hline $\mathrm{R} I \mathrm{-}-1 \mathrm{~B}$ & 2.48 & 167 & 0.2 & (52) & \\
\hline UR & 1.0 & 116 & \multicolumn{2}{|c|}{$\begin{array}{l}\mathrm{G}=2.95 \mathrm{~N} / \mathrm{mm}^{2} \\
\tau_{\mathrm{wy}}=0.3 \mathrm{~N} / \mathrm{mm}^{2}\end{array}$} & $\begin{array}{l}\text { みかけ密度によ } \\
\text { る推定值 }\end{array}$ \\
\hline
\end{tabular}

（）：文献（6）による

$\sigma 0.2$ : 素材の $0.2 \%$ オフセット耐力

$\tau_{w y} \quad$ : ウレタンの降伏せん断耐力

\section{2 実験方法}

実験方法は模式的には図 2 に示すように、y 方向（図 1 参照）を 材軸方向とした試験体両端をカマボコ断面バー四本で挟み、中央は $\mathrm{H}$ 形断面部材二本の加力梁で挟んでそれを伸ばした先端を荷重 $P$ で引張り、その反力 $P$ を中心下部に取ることによりアーム $r$ との積 で試験体に据りを加えた。

実験装置は図 3 に示している。材端支点のカマボコ断面バーと試 験体表面の間には板厚 $9 \mathrm{~mm}$ 、幅 $150 \mathrm{~mm}$ で試験体寸法に合わせた 長さの、表面をテフロン加工した板が挟んである。試験体の断面形 状から単純据りの卓越することを想定しているが支点の反り拘束を 極力軽減させる為である。ただし中央加力点では対称条件から完全 反り拘束となる。実験装置の支点と加力点の詳細は図 3 に示してい るが、据りモーメント $T_{T}$ は（1）式となる。

加力は単調載荷とし、低い荷重で試験機と試験体の接触をなじま
せた後弾性勾配を確定し、その後崩壊に至らしめた。

変形の測定は図 3 (上図) の(1) (9)の変位計で㨭り角を計り、相 対㨝り角 $\theta$ として（2）式によって試験体の据り角を求めた。

$$
\begin{aligned}
& T_{T}=P r / 2 \quad(r=900 \mathrm{~mm}) \\
& \theta_{1}=\frac{\text { (3)-(1) }}{\ell_{T}} \\
& \theta_{2}=\frac{(6)-(4)}{\ell_{T}} \\
& \theta_{3}=\frac{\text { (9) }-(7)}{\ell_{T}} \\
& \theta=\theta_{1}-\frac{\theta_{2}+\theta_{3}}{2}
\end{aligned}
$$

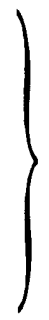

(2)

\section{3 実験結果}

実験により求めた据りモーメントと据り角との関係 $\left(T_{T}-\theta\right)$ を 図 $4(\mathrm{a})$ ～(e)に示す。いずれの図にも同一幅で長さの異なる三体の 結果が画かれている。材長と弾性剛性は対応しており長いほど剛性 は低い。

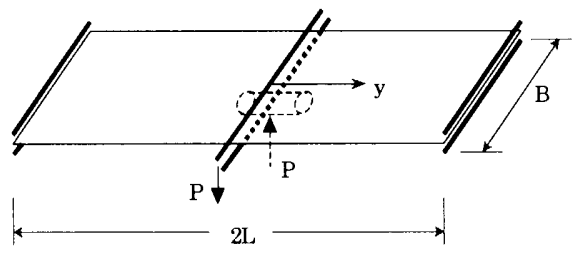

図 2 実験方法
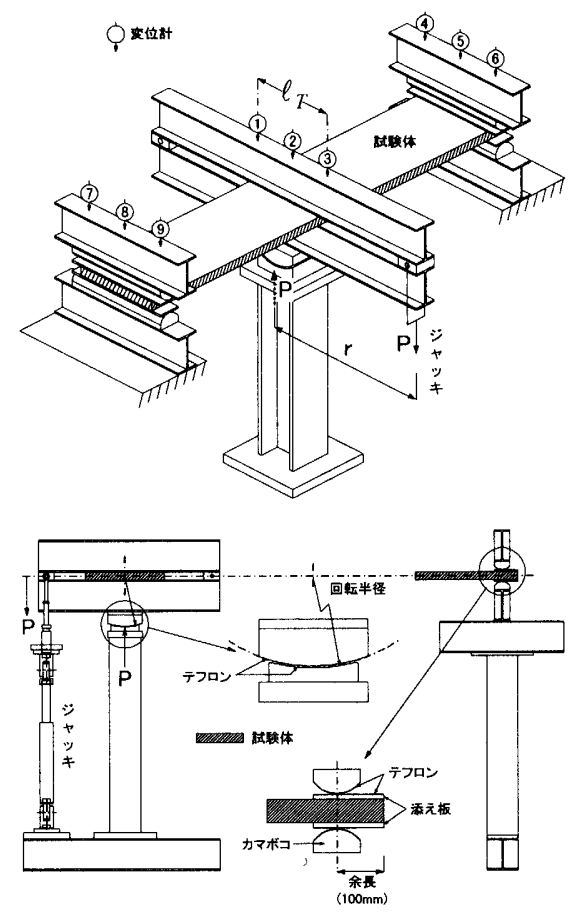

図 3 実験装置 


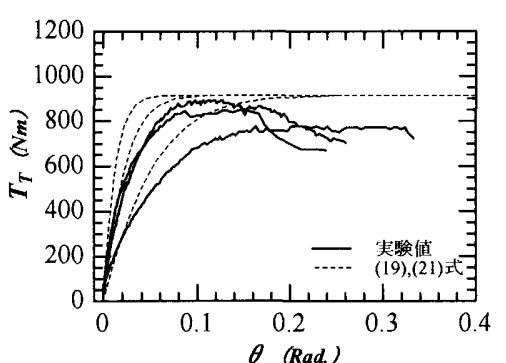

Breadth $=300 \mathrm{~mm}$

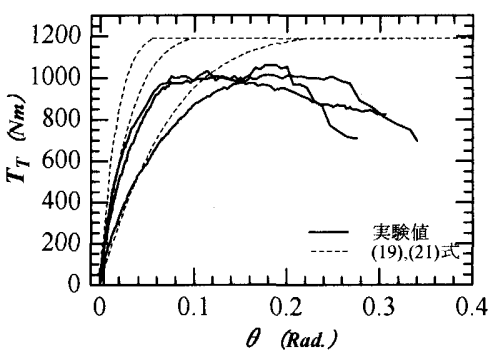

Breadth $=300 \mathrm{~mm}$

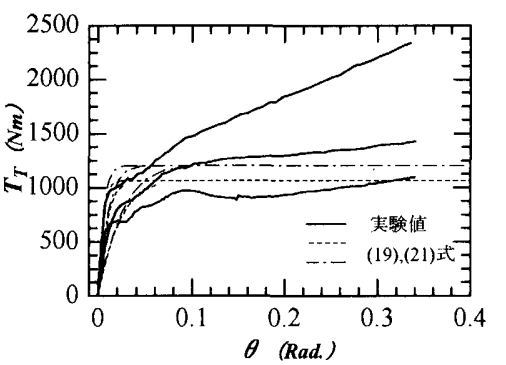

Breadth $=300 \mathrm{~mm}$

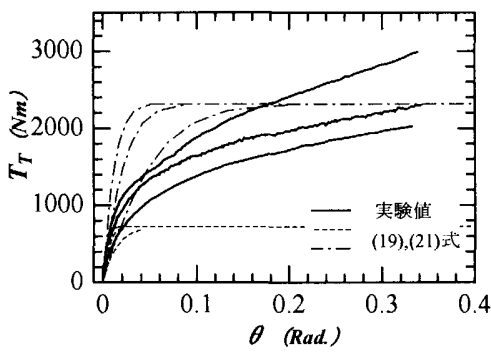

Breadth $=300 \mathrm{~mm}$

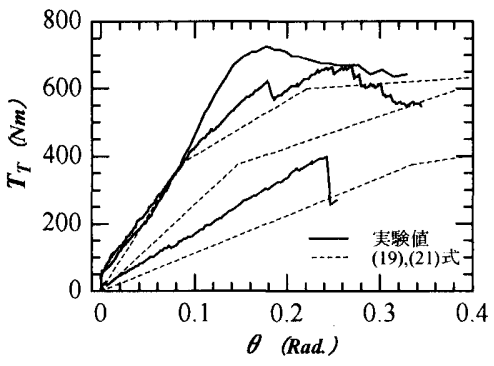

Breadth $=300 \mathrm{~mm}$

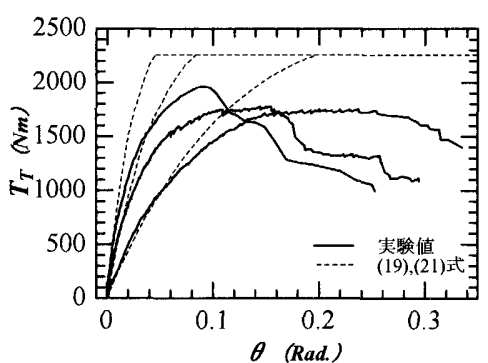

Breadth $=500 \mathrm{~mm}$

図 4(a) H I-1 Aシリーズ $\mathrm{M}_{\mathrm{T}}{ }^{-} \theta$ 関係

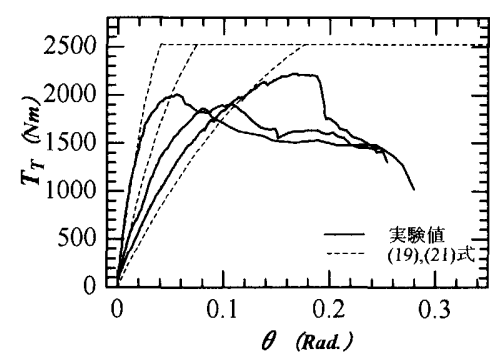

Breadth $=500 \mathrm{~mm}$

図 4(b) H I - 2 A シリーズ $\mathrm{M}_{\mathrm{T}}{ }^{-} \theta$ 関係
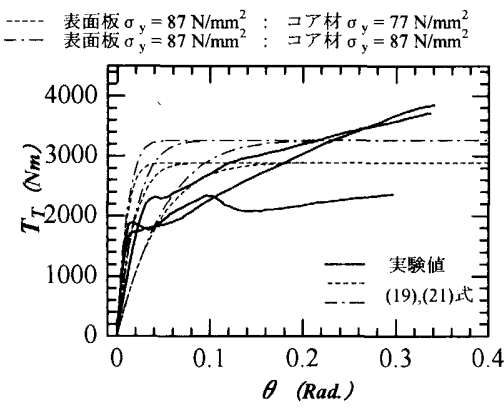

Breadth $=500 \mathrm{~mm}$

図 4(c) H II - 1 B シリーズ $\mathrm{M}_{\mathrm{T}}-\theta$ 関係

- 表面板 $\sigma_{y}=167 \mathrm{~N} / \mathrm{mm}^{2}:$ : コア材 $\sigma_{y}=52 \mathrm{~N} / \mathrm{mm}^{2}$

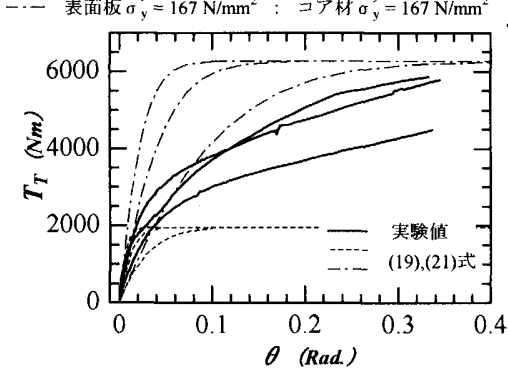

Breadth $=500 \mathrm{~mm}$

図 4(d) R II - 1 Bシリーズ $\mathrm{M}_{\mathrm{T}}-\theta$ 関係

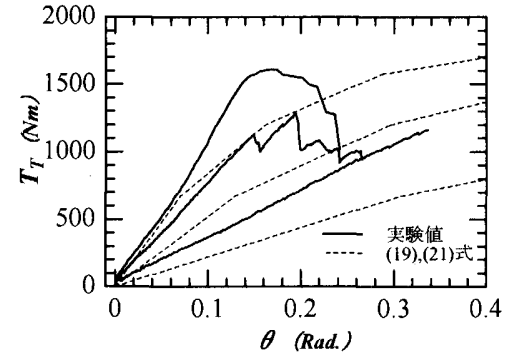

Breadth $=500 \mathrm{~mm}$

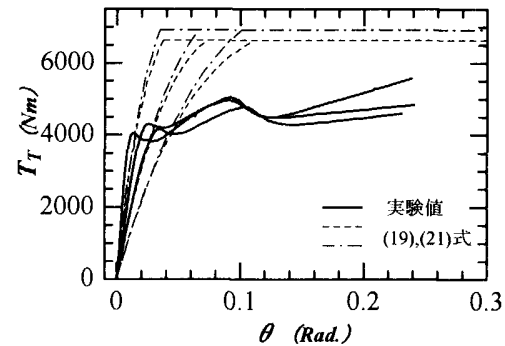

Breadth $=800 \mathrm{~mm}$

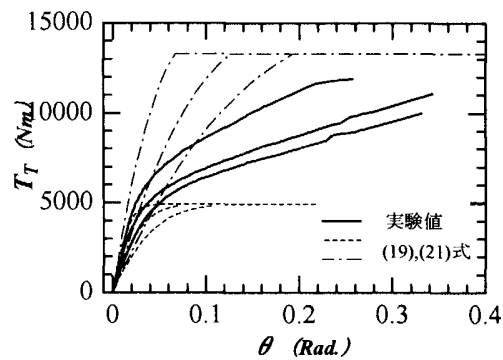

Breadth $=800 \mathrm{~mm}$

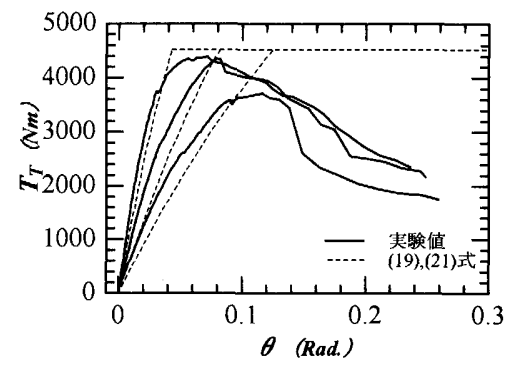

Breadth $=800 \mathrm{~mm}$

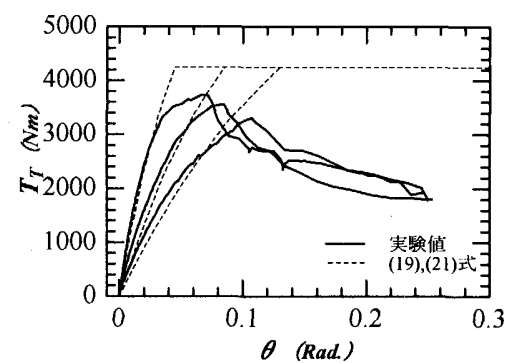

Breadth $=800 \mathrm{~mm}$

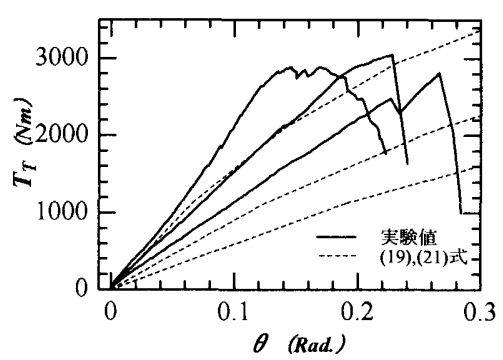

Breadth $=800 \mathrm{~mm}$

図 $4(\mathrm{e}) \mathrm{UR}$ シリーズ $\mathrm{M}_{\mathrm{T}}{ }^{-} \theta$ 関係 
図 4 (a) (b) は接着ハニカムパネルで、コア寸法が異なる。コア寸 法の小さい $2 \mathrm{~A}$ シリーズの方が耐力は高い。大変形に伴い表面板接 着部の剥離によりいずれも最大耐力以降耐力の劣化が見られる。図 4 (c) (d)はロウ付けパネルで、コアの形状が異なるがコア寸法は等 しい。表面板は同質に計画されたが素材試験によれば丸コアの方が 八ニカムのおよそ 2 倍の強度を持つ。この表面板強度差の影響が大 きいものと思われ、丸コアパネルの耐力の方が高い。ろう付けの場 合は、二次勾配として耐力の上昇が認められ、試験機のストローク で載荷限界をむかえている。八ニカムコアで不安定な性状を示寸が 丸コアでは安定して耐力が上昇している。これはハニカムコアでは コアの局所的な破壊によるものと思われる。図 4 (a) (b) と (e) は八ニ カムコアとウレタンコアの差である。ウレタンコアパネルも接着八 ニカムパネルと同様表面板接着部の剥離による耐力劣化を示す。耐 カは八ニカムコア (a)のほぼ $80 \%$ 程度で、剛性は低い。

\section{3.マルチセル置換}

3. 1 マルチセルの単純椖り

図 5 に示すような中空矩形断面に外壁と等厚な隔壁を二枚対称に 配したマルチセルパネルを考える。

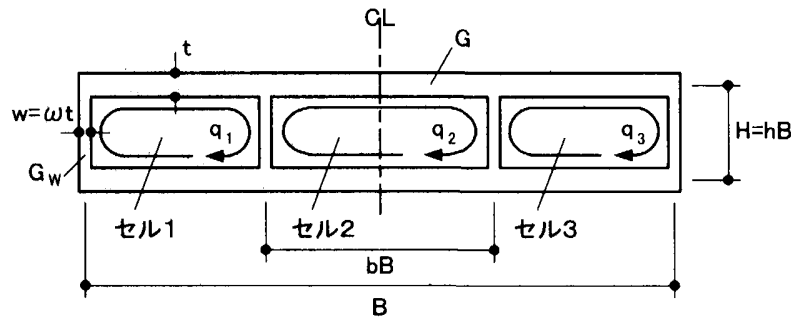

図 5 マルチセルパネル

単純据りに伴ら反り変形 $u_{\theta}$ とせん断変形 $u_{\gamma}$ を等しくおけば、パ ネル長さを $L$ 、セル各辺のせん断流と板厚の一般表示を $q, t$ として $\oint \frac{q}{t G} d s=2 A_{i} \theta / L$

ここに $\oint d s$ は各セルの全周にうたる積分、 $A_{i}$ はセル面積である。こ れより図 5 を参照して 3 つのセル 1 〜 3 に対して連立方程式を求め ればこれを解いてせん断流 $q_{i}$ が得られる。

$q_{1}=q_{3}=[\{b(1-b)+c\} /\{b(1-b+c)+c(1+c)\}] h t B G \theta / L$ $q_{2}=[\{b(1-b+c)+c\} /\{b(1-b+c)+c(1+c)\}] h t B G \theta / L$ ここにc $=\frac{G}{G_{w}} \frac{h}{\sigma}$ で、G，G $G_{w}$ は表面板と隔壁のせん断剛性である。 従って $q_{2}$ に対する隔壁のせん断流 $q_{w}$ の比率は次式となる。

$\overline{q_{w}}=\left(q_{2}-q_{1}\right) / q_{2}=c b /\{b(1-b+c)+c\}$

(6)式を種々の隔壁の位置 $b$ に対して示したものが図 6 である。

実験で用いられたアルミニウムコアパネルの表面板とコア材厚、 断面形状を考慮すれば

$c=0.78 \sim 2.08$

これより隔壁のせん断流の影響を次式で仮定できる。 $\overline{q_{w}}=b / 2$

（7)式より

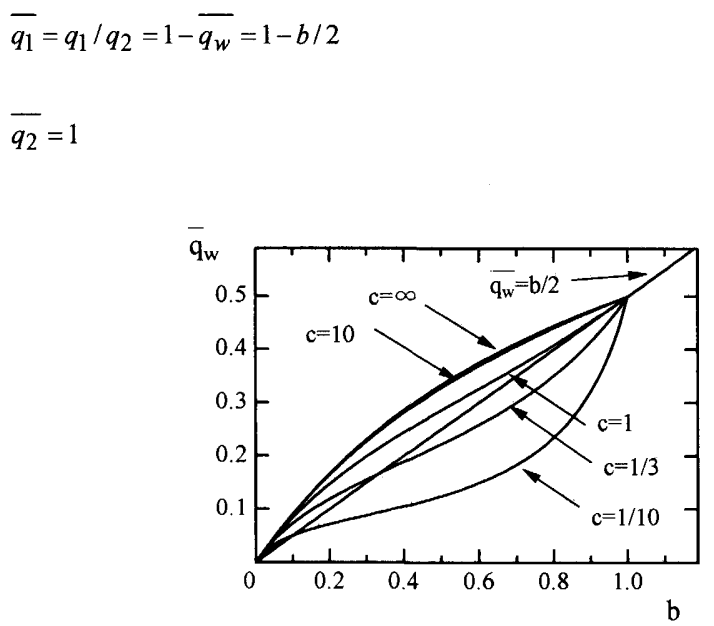

図 6 内壁せん断流の影響
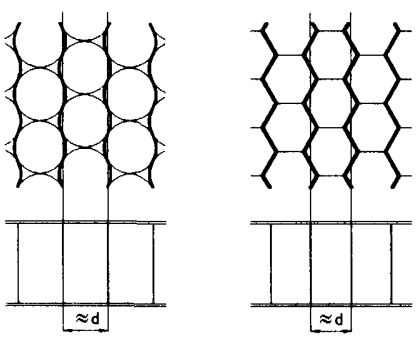

図 7 隔壁の仮定

\section{2 サンドイッチパネルへの適用}

アルミコアパネルを $N$ 個の等しいセルを持つ集合体のマルチセ ルとみなす。 $N$ は幅をコア寸法で除した $N=B / d$ とする(図 7 参照)。 今ここで、その中の任意の対称な 2 枚の隔壁のマルチセルを考え、 その幅を $b_{i} B$ とする。ここに $b_{i}=1-2 i / N$ である。図 5 より㨝りモ 一メントは、次式より求めることができる。

$\Delta T_{i}=\left[4 A_{1} q_{1}+2 A_{2} q_{2}\right]_{i}=\left[\left(1-b_{i}\right)\left(1-b_{i} / 2\right)+b_{i}\right] 2 A q_{2}$

$$
=\left[1-\frac{i}{N}+\frac{2 i^{2}}{N^{2}}\right] 2 A q_{2}
$$

$$
A=h B^{2}
$$

$N$ 個のセルを持つマルチセルの㧖りモーメントに対して、簡単のた め(9)式を $i=0 \sim N^{\prime}$ まで重畳して求める。 $N^{\prime}$ は $N / 2$ 以下の自然数で $N$ が偶数のとき $N^{\prime}=N / 2$ 奇数のとき $N^{\prime}=(N-1) / 2$ である。

$T_{N^{\prime}}=\frac{1}{N^{\prime}+1} \sum_{i=0}^{N^{\prime}} \Delta T_{i}=\left[\frac{11}{12}+\frac{1}{12 \bar{N}}\right] 2 A q_{2}$

$$
\bar{N}=\left\{\begin{array}{l}
N^{\prime}: N \text { が偶数 } \\
N: N \text { が奇数 }
\end{array}\right.
$$

各セルのせん断流 $q_{i}$ が全て等しい場合は $q_{w}=0$ となり、隔壁の影 響は無い。これは表面板と外壁のみの、いわゆる中空矩形断面の㨝 りと等価となる。 


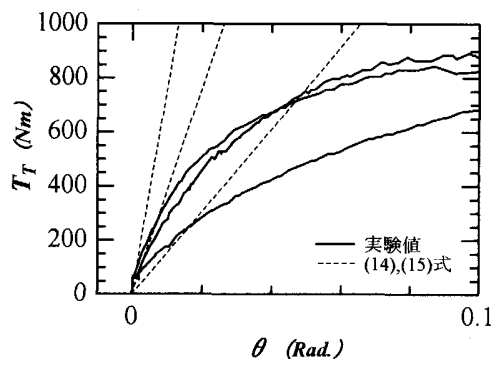

Breadth $=300 \mathrm{~mm}$

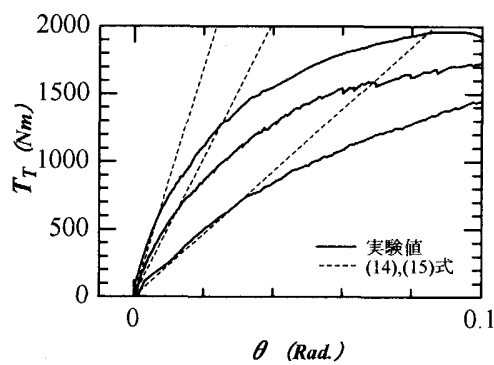

Breadth $=500 \mathrm{~mm}$

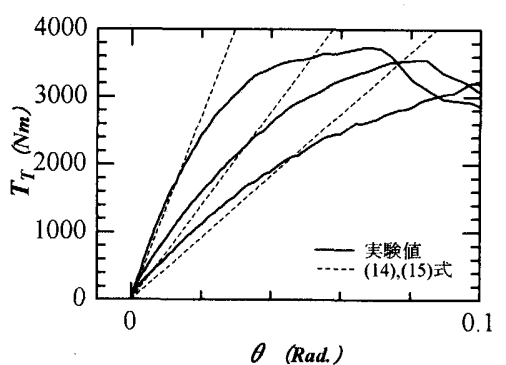

Breadth $=800 \mathrm{~mm}$

図 9 (a) 弾性勾配（理論值）との比較「接着ハニカム（コアサイズ $12.7 \mathrm{~mm}$ )」

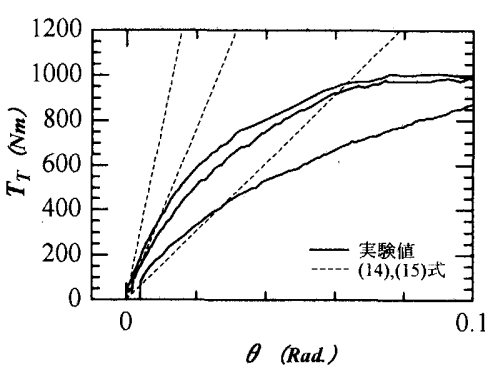

Breadth $=300 \mathrm{~mm}$

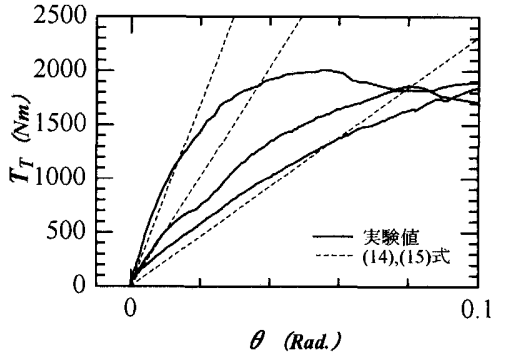

Breadth $=500 \mathrm{~mm}$

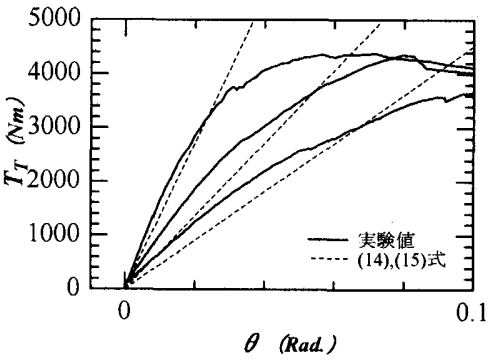

Breadth $=800 \mathrm{~mm}$

図 9 (b) 弾性勾配（理論值）との比較「接着ハニカム（コアサイズ $9.5 \mathrm{~mm} ） 」$

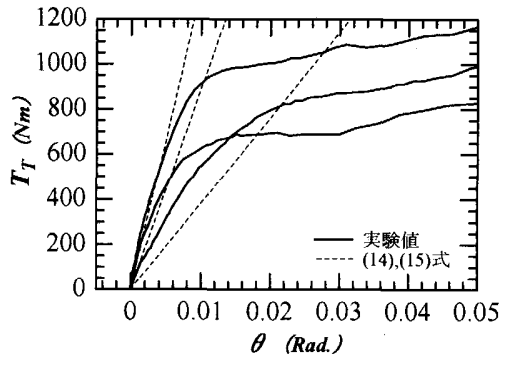

Breadth $=300 \mathrm{~mm}$

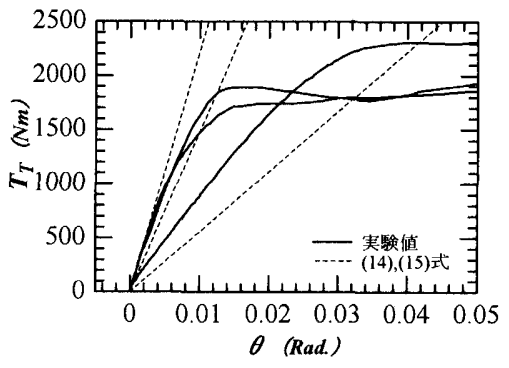

Breadth $=500 \mathrm{~mm}$

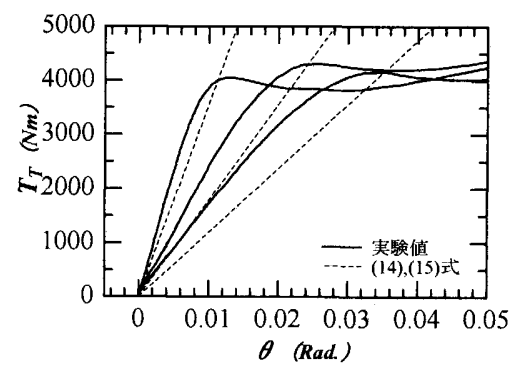

Breadth $=800 \mathrm{~mm}$

図 9 (c) 弾性勾配（理論値）との比較「ろう付けハニカム（コアサイズ $20 \mathrm{~mm}$ )」

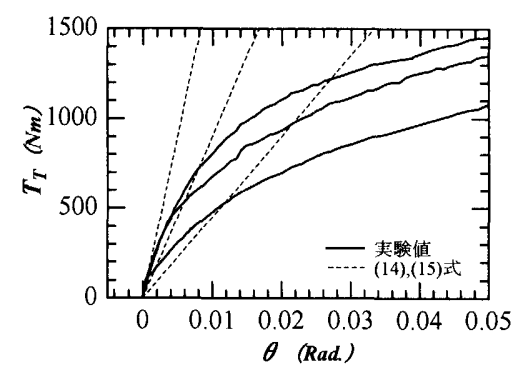

Breadth $=300 \mathrm{~mm}$

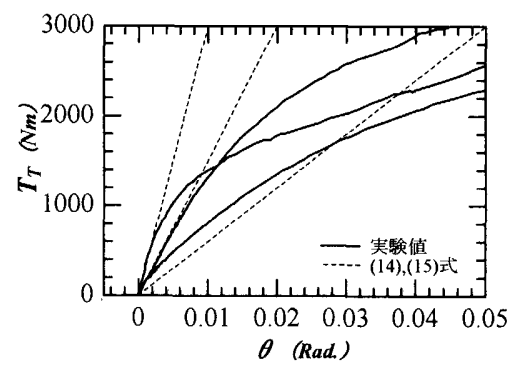

Breadth $=500 \mathrm{~mm}$

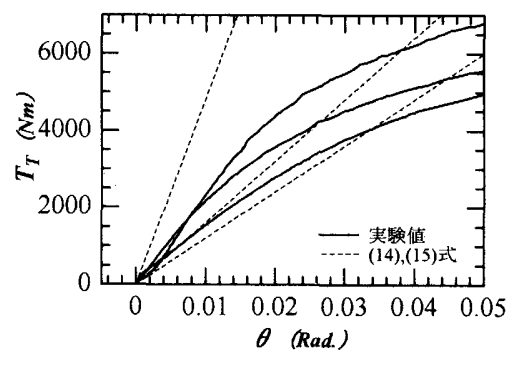

Breadth $=800 \mathrm{~mm}$

図 9 (d) 弾性勾配（理論値）との比較「「うう付け丸コア（コアサイズ $28 \mathrm{~mm}$ )」

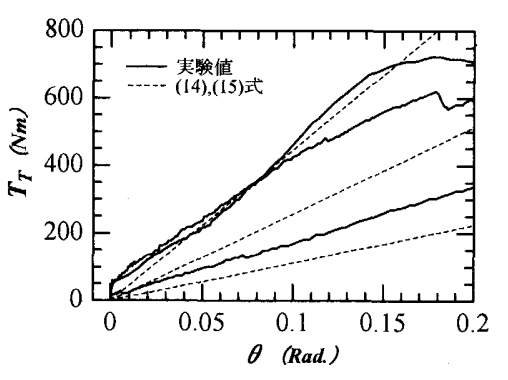

Breadth $=300 \mathrm{~mm}$

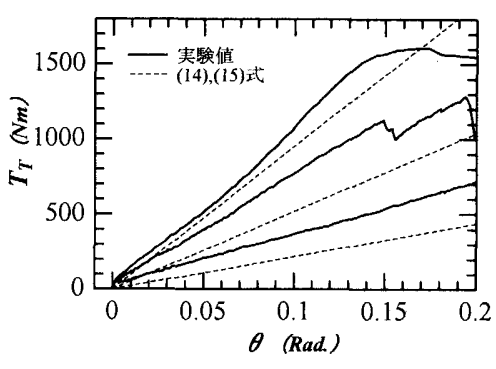

Breadth $=500 \mathrm{~mm}$

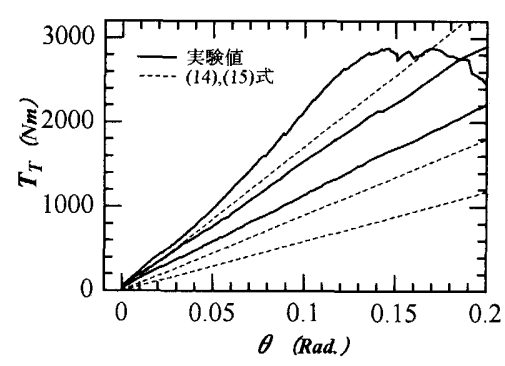

Breadth $=800 \mathrm{~mm}$

図 9 (e) 弾性勾配（理論値）との比較「ウレタンコア」 
$T_{1}=2 A q_{2}$

(10)式 $(11)$ 式より、隔壁を無視して据り剛性を評価する。

$T=2 A q$

(3) 式により

$q=G[h t B /(1+c)] \theta / L$

これより据り剛性 $G J$ は次式で表わす事ができる。

$T=G J \theta / L$

$G J=G\left\{2 h^{2} /(1+c)\right\} B^{3}=2 A^{2} /\left(\frac{B}{G t}+\frac{H}{G_{w} w}\right)$

外壁の降伏せん断流 $q_{w y}$ が表面板の降伏せん断流 $q_{t y}$ より小さい とき降伏は外壁に生じ、降伏㨭りモーメントは(12)式より

$T_{y}=2 A q_{w y}$

図 8 を参照して、以降順次内側の隔壁が降伏し、表面板せん断流が 降伏するまで耐力上昇するとすれば、最大耐力は次式となる。

$T_{u}=\sum_{i=0}^{n} b_{i} T_{y}=T_{y}(n+1)(1-n / N)$

ここに $\mathrm{n}$ は次式を満足する自然数である。

$n=q_{t y} / q_{w y} . \quad\left(\leqq N^{\prime}\right)$

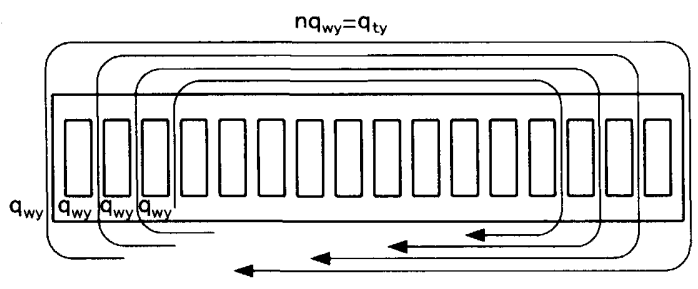

図 8 降伏後のせん断流

(17)式より外壁から $j$ 番目の内側の隔壁まで降伏した時の摸りモ ーメントは、次式で表わされる。ただし、 $j \leqq n$

$T j=\sum_{i=0}^{j} b_{i} T_{y}=T_{y}(j+1)(1-j / N)$

この時の接線据り剛性は(15)式より $B=b B 、 H=h B$ として

$G J_{j}=G\left\{2 h^{2} b_{j}^{2} /\left(b_{j}+c\right)\right\}^{3} B^{3}$

従って $T_{j}$ 時の据り変形は、次式となる。

$\theta_{j}=\sum_{i=0}^{j} \frac{b_{i} T_{y} L}{G J_{i}}=\frac{T_{y} L}{2 A G h t B}\left[(j+1)+c \sum_{i=0}^{j} \frac{N}{N^{\prime}-2 i}\right]$

ウレタンコア材の場合は、幅方向に厚さ $H$ で分割しその中心に位 置する $w=H$ の隔壁を考える。また $G / G_{w}=9,000$ とする。この時 $c$ の値は最大 40 以下であり、図 6 より (7)式をほぼ满足する。

\section{4. 㨝り挙動評価}

(14)(15)式で表わされる弾性勾配を実験結果と比べたのが図 9 (a) 〜(e)である。図 4 と同様にそれぞれ同断面について材長を変化させ た 3 体づつをまとめて示した。評価式はいずれも実験結果の初期勾 配をウレタンも含めほぼ安全側に評価している。
図 4 中に(19),（21)式より求めた㨝り変形性状を点線で示してい る。図 4 (a)(b)の接着パネルはコアの機械的性質が不明のため表面板 と等しくとったが、最大耐力まで評価式は比較的よく追従している。 (18)式から判断すれば最大耐力がほぼ表面板の降伏で決まるためと 思われる。図 4 (c)(d)のロウ付けパネルはコア材の機械的性質を表面 板の值と表 3 中（）で示した值を共に示した。見掛上の降伏は後者 の評価位置に近いが以降素材の歪硬化の影響が考えられる。ちなみ に後者の素材の引張強さは八ニカムコアで $153 \mathrm{~N} / \mathrm{mm}^{2}$, 丸コアで $132 \mathrm{~N} / \mathrm{mm}^{2}$ である。丸コアパネルでは表面板の強度を考慮すれば大 きな耐力の上昇がうなづける。図 4 (e)のウレタンパネルではマルチ セルに置換する大胆な仮定にもかかわらずよく対応している。

\section{5. 結び}

アルミニウム合金サンドイッチパネルの㨭り性状を実験的に確認

し、簡単なマルチセル置換によりその挙動の説明を試みた。

1. 初期の㨝り剛性は、外壁のみとした中空矩形断面評価で 推測が可能である。

2. 㨝り耐力はコア材が表面板よりそのせん断耐力が低い場 合、外壁から順次隔壁の内側一降伏していくものとして 評価できるものと思われる。

3. 接着八ニカム及びウレタンパネルは最大耐力以降耐力劣 化する。

4. ロウ付けパネルは見掛上の降伏から二次勾配で耐力上昇 が認められる。八ニカムコアはれコアに比較して耐力上 昇に対して不安定な挙動を示す場合がある。

尚本研究は、アルミニウム建築構造協議会（松岡建会長）におけ る研究活動の一環として行われたものである。

参考文献

(1)井上哲郎、木村衛、橋本篤秀: アルミニウム合金を用いた建築構 造に関寸る研究（その 54）一㨭り実験一日本建築学会大会学術講 演梗概集、C-1、pp. 499〜500、2001.9

(2)木村衛、井上哲郎、橋本篤秀: アルミニウム合金を用いた建築構 造に関する研究（その 68）一サンドイッチパネルの据り計画一日 本建築学会大会学術講演梗概集、C-1、pp. 573 574、2003.9

(3) 日本アルミニウム協会: アルミニウム材料の特性データベースの 整備、pp339〜356、2001.3

（4)例えば E.Schapitz（石崎訳）：軽量構造の力学、コロナ社、1966 (5)アルミニウム建築構造協議会 : アルミニウム建築構造設計規淮 ・ 同解説 2003.5

(6) 寺西学、岡田久志、木村衛、橋本篤秀: アルミニウム合金を用い た建築構造に関する研究（その 38）一サンドイッチパネルの面外 曲げ実験 I一日本建築学会大会学術講演梗概集、C-1、pp. 1013 $\sim 1014 、 2000.9$ 